\title{
PROBLEMS AND PROSPECTS OF HYDRAULIC MODELLING FOR ENVIRONMENTAL FLOWS ASSESSMENT STUDIES IN EAST AFRICA
}

\author{
Preksedis M. Ndomba* and Joel Nobert \\ Department of Water Resources Engineering, \\ University of Dar es Salaam, Tanzania \\ Email of corresponding author*: pmndomba2002@yahoo.co.uk
}

\begin{abstract}
The objective of this paper is to document the problems and prospects of hydraulic modelling for Environmental Flows Assessment (EFA) studies based on selected case studies. Most of studies in East Africa use Holistic methodologies. An ideal data set for defining river hydraulics for most of these methods would be six data points of stage measurements over a good distribution of discharges, the stage of zero discharge and some flood-related data. Besides, in East African region EFA studies suffer from data scarcity (i.e., poorly gauged sites) and limited expertise and funding. The hydraulics studies conducted by the authors entailed desktop research, limited fieldwork for data collection, data analysis, and modelling. The hydraulic models (HEC-RAS and PHABSIM) used are governed by Manning and/or Energy equation(s) to simulate hydraulics. The optimized sensitive parameters include roughness number, expansion/contraction coefficients, roughness modifier and Beta coefficient. Data collected at medium flow, bank full discharge information at neighbouring flow gauging stations, information from previous studies, field observations on flow regimes and professional experience validated the performance of these models. The geometric characteristics for extended floodplains and/or swamps were derived from a calibrated NASA Shuttle Radar Topographic Mission (SRTM) Digital Elevation Models (DEM) of 30 arc-seconds resolution under HEC-GeoRAS GIS extension Environment. The modelling results were considered satisfactory because the relative errors for most of applications fall below 20\%. The good performance achieved is attributed to the instituted quality control measures right from suitable sites selection to hydraulic modelling phases. Modelling results confidence rating of above 3 in a scale of 1 to 5 achieved depended upon the hydraulic complexity. Based on the satisfactory results in the case studies, the authors would like to note that there are some prospects of carrying out hydraulic analysis in the regions with inadequate data. However, professional input is the key to successful modelling exercises. Therefore, follow research should use more data to verify the approach adopted.
\end{abstract}

Keywords: EFA, HEC-RAS, Holistic Methodologies, Hydraulic Modelling, PHABSIM

\section{INTRODUCTION}

Approaches of carrying out Environmental Flow Assessment (EFA) can be classified into a few general categories: Hydrologybased, Hydraulic rating, Habitat simulation and Holistic methodologies. The hydrological methods rely on the use of hydrological data, usually in the form of historical flow records, for making environmental flow recommendations (King et al., 2000). Hydraulic methods usually consider river width and wetted perimeter (Gippel and Stewardson, 1998) while habitat methods attempt to assess environmental flow requirements on the basis of detailed analyses of the suitability 
of instream physical habitat under different discharges using integrated hydrological, hydraulic and biological response data (Jowett, 1992). The results usually take form of habitat-discharge curves to predict optimum flows as environmental flow requirements. Holistic methods assume that the requirements of the complete ecosystem are integrated and considered (including the river channel, source areas, riparian zone, floodplain, etc.). The basis for most approaches in the latter method is a systematic construction of a modified flow regime on a month by month and element by element basis, which defines features of the flow regime to achieve particular ecological, geomorphological, water quality, social or other objectives of the modified system. Advanced holistic methods routinely utilize several tools found in hydrologic, hydraulic and habitat rating methods.

Three popular examples of holistic methodologies are (i) Building Block Methodology (BBM), (ii) Downstream Response to Imposed Flow Transformations (DRIFT), and (iii) The 'Savannah' Method. BBM approach involves a team of interdisciplinary scientists whereby information is summarized and scientists collaborate to reach a consensus about the flow needs of the river (1) it determines how much water is needed during low flow periods, (2) how many high flows or floods are needed, (3) how long should floods last, and (4) when should they occur. Overall prescription is presented as a set of flow targets for water managers. Some of the advantages of this methodology are recognition of the importance of a variable flow regime and prescribes quantitative flow targets for different periods of the year. Although to disadvantage, this method requires a lot of field-based data, highly quantitative, subsistence uses not considered and applied just for one river.

Understanding how change to a flow regime affects in stream ecological values requires an understanding of hydraulics, which refers to water depth, velocity, wetted perimeter and width of water surface. Hydraulics is altered by a change in flow and in turn the change in hydraulics leads to changes in the instream ecological values. Hydraulic conditions are determined by the interaction of the velocity and channel cross-section geometry with flow. For a particular cross-section, the hydraulic conditions depend on channel hydraulic roughness, channel morphology comprising slope and channel geometry.

Local hydraulics and channel morphology are the primary determinants of the availability of physical habitat which, in turn is a major determinant of ecosystem function (King et al., 2000). For instance, the depth of a river channel is important in determining the meso-habitat characteristics. It influences the living space available for biota and its changes also may affect the habitat suitability of a reach for plants, invertebrates, fish and birds (Jowett, 1992). For an individual cross section wetted perimeter is used as a measure of the availability of aquatic habitat over a range of discharges. Fish of many species move into inundated vegetation at high water to breed and feed and back to low water channels as levels fall (Mwamila et al., 2008). The wetted width of river channels is directly important to biological conditions as it controls the total area available for bottom living organisms. Its changes predominantly occur as a result of changes in flow and it is related to changes in water depth. The ratio of change in depth to change in width varies considerably depending on the cross-sectional profile of a particular reach. The largest changes in width will occur in rivers with shallow cross-sections and the least reduction in deep cross-sections (Biggs, 1982). There may be a critical water level for a reach such that flow reductions down to this level will have little effect on width. Alternatively, increased flow will have little effect on width up to the critical level. After the critical level is reached, increases or 
decreases of flow may result in comparatively large increases or decreases in width (Biggs, 1982). The velocity of flow is critical for the respiration and reproduction of some species (Allan, 1995). Reduction or increases in water velocity can therefore impact positively or negatively on many biological functions. It should be noted here that the hydraulic effects of change in flow regime differ for different river types. These differences can be explained by considering the natural flow regime and channel type (Biggs, 1982).

An ideal data set for defining river hydraulics for most of these EFA methods would be six data points of stage measurements over a good distribution of discharges, the stage of zero discharge and some flood-related data (King et al., 2000). However, most of studies in the East African region suffer from hydrological data scarcity (i.e., poorly gauged sites) and limited expertise and funding (Ndomba, 2013; McClain et al., 2013). As a result development projects such as EFA for a certain river reach would require initiation of stream flows sampling programme. These EFA initiatives are characterized as short-time lived, ill-funded, and project based. It has been difficult to adequately sample the stream flows regime of a study site, as only 1 to 3 data points are used (McClain et al., 2013).

Therefore, in order to interpolate or extrapolate hydraulic parameters other than the measured ones, a hydraulic model was considered necessary. Besides, it aims at producing physical parameters for purpose of linking them to some biological observations. Moreover, in a holistic scenario-based approach, a great number of various flow patterns have to be tested. The only alternative offering quick computations of hydraulic problems is the use of a model. It should be noted that in literature there are several hydraulic models which are used for simulating non-uniform steady flow in natural rivers. Selection criteria of these models depend on available data and the final use of outputs. Among them are Hydrologic Engineering CentreRiver Analysis System (HEC-RAS), Physical Habitat Simulation Model (PHABSIM), Mott MacDonald's in House software (HYDRO), etc. Several of Habitat Hydraulic models have been derived from the PHABSIM (Bovee, 1982). Some of these models are Riverine HABitat SIMulation (RHABSIM), River hYdraulic and HABitat SIMulation (RYHABSIM) (Jowett, 1992) or HABIOSIM. Even more softwares were developed outside the PHABSIM framework: Evaluation de 1'Habitat (EVHA), River System Simulator (RSS) and Computer Aided SIMulation of habitat. Most of these models are based on the principle of energy conservation and use the flow, slope, hydraulic roughness, the hydraulic properties of the cross-sections, water profiles, and upstream and/or boundary conditions to calculate the longitudinal flow profile. Many different EFA hydraulic models exist and were created to fulfil different purposes and therefore a study must critically choose an appropriate model. To the best knowledge of the authors little has been done on EFA in East African region.

The objective of this paper is therefore to document and report on problems and prospects of Hydraulic Modelling for selected EFA Studies in data poor catchments of East Africa.

\section{DESCRIPTION OF THE STUDY CASES}

In this paper, four (4) study cases (Figure 1 and Tables 1-3) are discussed in detail. They include Mara River Sub-Basin, Wami River Sub-Basin, Great Ruaha River Basin, and Pangani River Basin.

\section{Mara River Basin}

Mara River Sub-basin (MRB) is an international basin shared between Kenya and Tanzania (Fig. 1). The Mara river basin is about $13,750 \mathrm{~km}^{2}$ of which about $65 \%$ is 
located in Kenya and 35\% in Tanzania. The transboundary Mara River basin is located roughly between $33^{\circ} 47^{\prime}$ and $35^{\circ} 47^{\prime}$ Longitudes, East and between $0^{\circ} 38^{\prime}$ and $1^{\circ}$ 40' Latitudes, South. The basin highlands are at 3,100 m.a.s.l and the lowlands are at 1,140 m.a.s.1 at Lake Victoria. The basin covers Nakuru, Bomet, Narok, and Trans Mara administrative districts in Kenya and Tarime, Musoma Rural and Serengeti administrative districts in Tanzania. Mara River runs through the Maasai Mara Game Reserve on the Kenyan side and the Serengeti National Park on the Tanzanian side and drains its water into Lake Victoria. There are numerous streams in the basin that drains into the Mara River. The main tributaries in the upper and middle basin are Amala, Nyangores and Engare Ngobit. In the lower basin, the Talek and Sand Rivers, which originate from Loita hills and flow through the Loita plains also drain in to the river. The Amala and Nyangores tributaries are the only permanent tributaries into Mara River. On the Tanzanian side, Rivers Mori, Kenyo, Tambora and Nyambire drain the basin (Mati et al., 2005).

\section{Wami River Sub-basin}

The Wami River Sub-Basin (WRSB) is located between $5^{\circ} \mathrm{S}-7^{\circ} \mathrm{S}$ and $36^{\circ} \mathrm{E}-39^{\circ} \mathrm{E}$. The sub basin extends from the semi-arid Dodoma region to the humid inland swamps in Morogoro region and Saadani Village in the coastal Bagamoyo district (Fig. 1). It encompasses an area of approximately $43,946 \mathrm{~km}^{2}$. The Wami River begins at the Dogwai River, which is located approximately $120 \mathrm{~km}$ northeast of Dodoma municipality at the Chiole Hill in ChanDama highlands. From the Chiole Hill, the river flows down towards the south where it is commonly known as the Kinyasungwe River. The River passes through Dabalo natural reservoir at an approximate elevation of 1,000 m.a.s.l. (Fig. 1). The river further flows down to south-east direction and the river name at this point is called Mkondoa River. The River passes through the Lake Nzuhe and
Lake Gombo in the suburbs of Mpwapwa and Kilosa (Fig. 1). At Mkata Plain downstream of Kilosa, the River turns to northeast and joints with Wami tributary which comes from the west-southwest. The river at this point is called Wami River. The river meets Kisangata River, Tami River and Mkundi River and then flows in the northeast to cross the National Road at Dakawa village. After that, Wami River joins with Mjonga/Diwale and Lukigula Rivers around Kiromo village in downstream and flows towards east. At Mandera, the River crosses the National Highway linking Chalinze and Segera and flows into the Indian Ocean through the estuary in the Wami delta.

Climatic conditions in the Wami River sub basin are both spatially and seasonally variable. Average annual rainfall across the Wami sub basin is estimated at 550-750 $\mathrm{mm}$ in the highlands near Dodoma, 900$1000 \mathrm{~mm}$ in the middle parts of the sub basin near Dakawa, and at the river's estuary in Bagamoyo. Most parts of the Wami River sub-basin experience marked differences in rainfall between wet and dry seasons. Although there is some interannual variation in timing of rainfall, dry periods typically occur during July-October and wet periods occur during NovemberDecember (first rains) and March-June (long rains). Average monthly minimum and maximum temperatures are almost the same throughout the basin. The coldest month is August $\left(18^{\circ} \mathrm{C}\right)$ and the hottest month is February $\left(32^{\circ} \mathrm{C}\right)$. The annual average temperature is approximately $26^{\circ} \mathrm{C}$. Evaporation is estimated at $2500 \mathrm{~mm} / \mathrm{yr}$., a value that exceeds the average annual rainfall in the semi arid region of Dodoma. However, in Morogoro and the coastal regions, evaporation is $1800 \mathrm{~mm}$ with relative humidity of $50 \%$ and $62 \%$, respectively.

\section{Great Ruaha River Basin}

The Great Ruaha is a river in south-central Tanzania. The river flows through the Usangu wetlands and the Ruaha National 
Park east into the Rufiji River. The population of the basin is mainly sustained by irrigation and water-related livelihoods such as fishing and livestock keeping. Great Ruaha is about $475 \mathrm{~km}$ long, its tributary basin has a catchment area of $83,979 \mathrm{~km}^{2}$ and the mean annual discharge is $140 \mathrm{~m}^{3} / \mathrm{s}$. The Great Ruaha River supplies 22 per cent of the total flow of the Rufiji catchment system. Thirty eight species of fish have been identified in the Great Ruaha River. The river's headwaters are in the Kipengere mountain range. From there the Great Ruaha River descends to the Usangu plains, an important region for irrigated agriculture and livestock in Tanzania. The river eventually reaches the Mtera Dam and then flows south-eastwards to the Kidatu Dam. The two hydro-electric plants at Mtera and Kidatu generate about 50 percent of the Tanzania's electricity. The river continues south-eastwards and flows across the Selous Game Reserve before discharging into Rufiji River. The major rivers contributing to the Great Ruaha River are Lukosi, Yovi, Kitete, Sanje, Little Ruaha, Kisigo, Mbarali, Kimani and Chimala whereas the small ones include Umrobo, Mkoji, Lunwa, Mlomboji, Ipatagwa, Mambi and Mswiswi rivers. Decreased flows in the Great Ruaha have been attributed to uncontrolled abstractions and poor water management, with the large rice irrigation schemes playing a major role in water abstractions.

\section{Pangani River Basin}

The Pangani River Basin (PRB) is located in the North-Eastern part of Tanzania and covers an area of about $42,200 \mathrm{~km}^{2}$, with approximately $5 \%$ of area in Kenya. In Tanzania, the Basin is spread over four administrative regions: Kilimanjaro, Arusha, Manyara and Tanga. The Pangani River has two main tributaries, the Kikuletwa and the Ruvu, which join at Nyumba Ya Mungu (NYM), a reservoir with surface area of $140 \mathrm{~km}^{2}$. The effluent of the reservoir is known as the Pangani River, which flows for $432 \mathrm{~km}$ before emptying into the Indian Ocean. The NYM Reservoir is the largest water body in the Basin. There are three others: Lake Ambussel, and, lying on Tanzania's border with Kenya, Lakes Chala and Jipe. The PRB is thought to have about 90,000 ha of swamp, most of which comprises the Kirua Swamps, lying downstream of the Nyumba Ya Mungu (NYM) Dam. Other swamplands are the Ruvu Swamp that lies at the point where the Ruvu River exits from Lake Jipe, and a swamp lying within main Ruvu and Kikuletwa Rivers floodplains and bordered to the South by NYM reservoir. The latter swamp area is estimated to cover some $40 \mathrm{~km}^{2}$.

Table 1: Description of the Study Cases

\begin{tabular}{|l|l|l|l|c|}
\hline No. & Country & Study case & Purpose/Objective & Area $\left.\mathbf{( k m}^{\mathbf{2}}\right)$ \\
\hline 1. & $\begin{array}{l}\text { Kenya (KY) and } \\
\text { Tanzania (TZ) }\end{array}$ & Mara River Basin (MRB) & $\begin{array}{l}\text { Environmental Flow } \\
\text { Assessment (EFA) }\end{array}$ & 13,750 \\
\hline 2. & Tanzania (TZ) & $\begin{array}{l}\text { Wami River Sub-Basin } \\
\text { (WRSB) }\end{array}$ & Initial EFA (IEFA) & 40,000 \\
\hline 3. & Tanzania (TZ) & Great Ruaha River (GRRB) & EFA & 68,000 \\
\hline 4. & $\begin{array}{l}\text { Tanzania (TZ) and } \\
\text { Kenya (KY) }\end{array}$ & Pangani River Basin (PRB) & EFA & 42,200 \\
\hline
\end{tabular}




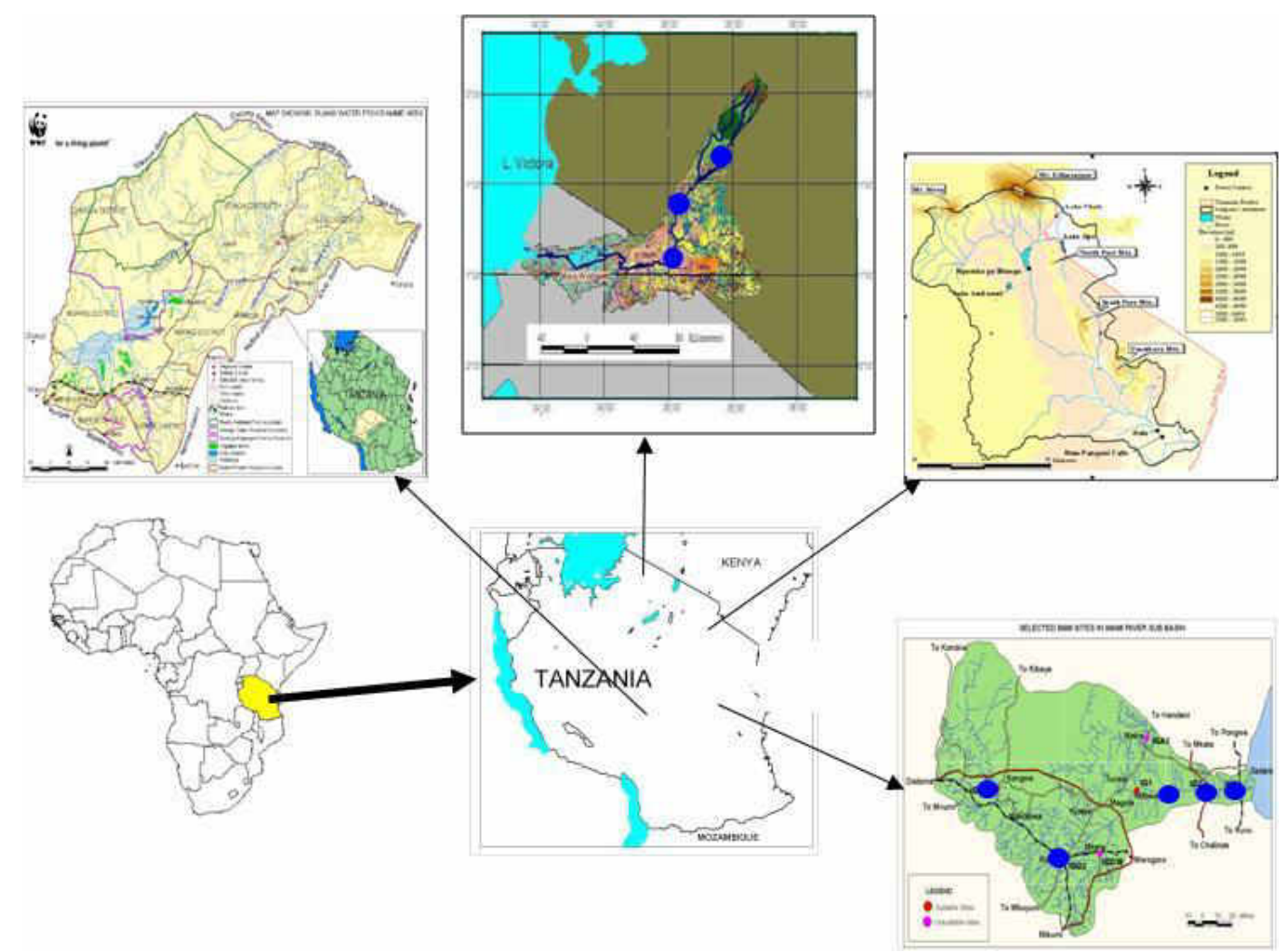

Figure 1: $\quad$ Location map of Environmental Flow Assessment (EFA) study cases in East Africa. Blue circles show the representative study sites.

\section{METHODS AND MATERIALS}

The method used includes available mathematical hydraulic models (i.e. HECRAS and PHABSIM), and limited fieldwork data and/or observations. The main steps in EFA studies entailed (i) determination of number of study sites, (ii) selection of representative sites, (iii) data collection and analysis, and (iv) hydraulic modelling.

\section{Selecting Representative Sites}

The criteria used for selecting suitable sites for the assessment of environmental flows are as recommended by King et al. (2000). They include ease of accessibility; habitat diversity; sensitivity of habitats to flow changes; suitability for measuring a rated hydraulic cross-section and for modelling discharges, velocities, and wetted perimeter at different water depths; proximity to a flow gauging site; representation of conditions in the river zone; and critical flow site (i.e. where flow will stop first if discharges are reduced). Besides, in this reconnaissance survey river reaches characterized by presence of both riffles, pools and runs were considered ideal for EFA studies. Reconnaissance survey is a preliminary survey, usually executed prior to mapping in detail and with greater precision and aims at selecting sites for EFA study.

For the study cases, the entire river could not be measured, mapped and characterized at a resolution appropriate to the riverine biotas, but only a few representative sites were selected as shown in Table 2. The most important criteria used for the sites selection is that it should satisfy hydraulic requirements, but at the same time represent critical and varied habitats for fish, aquatic invertebrate and riparian vegetation. Fish and invertebrate habitat are considered vital habitats as these habitats are mostly used to set the base flows. Many Instream Flow Requirements (IFR) studies conducted elsewhere (Arthington and Pusey, 1993; 
King et al., 2000) have indicated that the base flow component forms the largest part of the total flow volume, and higher flows the smaller component in perennial rivers. It is therefore more important to have the base flows as accurate as possible and the study sites be selected during the low flow season. In this study the representative sites for the case studies (Table 2) were identified during low /medium flows river conditions.

Table 2: $\quad$ Description of the Methods Used

\begin{tabular}{|c|c|c|c|c|c|c|c|c|c|}
\hline \multirow[b]{2}{*}{$\sum_{\sim}^{Z}$} & \multirow{2}{*}{ 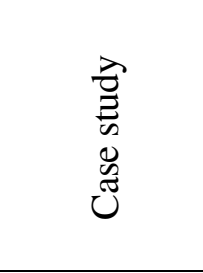 } & \multirow{2}{*}{ 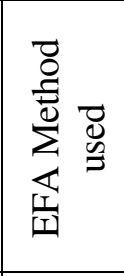 } & \multirow{2}{*}{ 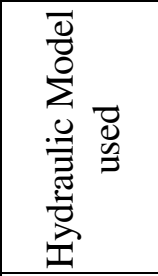 } & \multirow{2}{*}{ 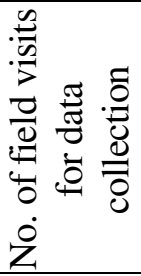 } & \multirow[b]{2}{*}{ 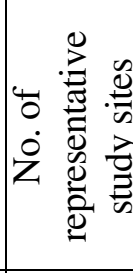 } & \multirow{2}{*}{ 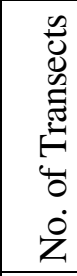 } & \multirow{2}{*}{  } & \multicolumn{2}{|c|}{$\begin{array}{l}\text { Scope/data } \\
\text { requirement }\end{array}$} \\
\hline & & & & & & & & 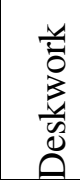 & 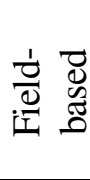 \\
\hline 1 & MRB (KY/TZ) & BBM & PHABSIM & 2 & 3 & $4-6$ & $67-77$ & $X$ & $\checkmark$ \\
\hline 2 & WRSB (TZ) & ASRM* & PHABSIM & 1 & 5 & 4 & $55-125$ & $\checkmark$ & $\checkmark$ \\
\hline 3 & GRRB (TZ) & BBM & PHABSIM & 1 & 2 & 4 & $144-359$ & $\checkmark$ & $\checkmark$ \\
\hline 4 & PRB (TZ/KY) & DRIFT & HEC-RAS & 0 & 1 & 47 & 135,000 & $\checkmark$ & $\mathrm{X}$ \\
\hline
\end{tabular}

Note: * ASRM stands for Adapted Savannah River Method

The rationale for selecting more than one site in the study area include: tributaries entering the system may introduce different channel, bank and/or habitat conditions which may need to be considered separately; various hydrological stage points are required within the system to cater for the inflows of tributaries and losses down the length of the system; the Ecological Management Class (EMC) of particular reach of the river may differ; and a river system displays biological diversity along its length and therefore a single site is unlikely to adequately reflect this range of diversity. However, the number of study sites in the system influences the cost and time required for the study, especially when it comes to components such as hydrology/hydraulics and ecology. The decision on how many sites are selected for this study was guided by the length and diversity of the rivers assessed; and a tradeoff between the need to characterize the river adequately and the constraint of time and resources available.

The process of selecting sites was a negotiated process involving Fluvial Geomorphologist, Hydraulic Engineer and Aquatic Ecologist whereby ecological variability and confidence had to be measured against hydraulic accuracy. A good ecological site having low confidence hydraulics, for example, was dropped because with inaccurate hydraulics, the resulting recommended flows would be meaningless.

It should be noted that minimum requirement for the hydraulic analysis at any site is surveyed cross-section in which flows have been measured at a various levels. This allows the calculation of the relationship between depth and the parameters such as current velocities, or river widths, flow area and wetted perimeter. However, a single cross-section survey can only provide flow parameters relationships for that one point, which may not reflect conditions along the river. In such kind of analysis the location of the cross-section at a critically flow-sensitive point is therefore essential. Habitat modelling, requiring a series of rated crosssections within a river reach, provides more realistic features of habitat change with changing flows. Therefore, in these case studies, the latter approach of rating many cross sections at representative sites reach was adopted (Table 2). Although, the 
method is time-consuming and resource intensive, it keeps at minimum the uncertainty of data analysis with data sets from one or two field trip(s). The study sites fell under various geomorphologic zones (Table 3). Besides, most of these river reaches are characterized by presence of riffles, pools and runs (Table 3 ).

\section{Data Types and Collection Technology}

The data collected include cross section geometry, reach lengths, water levels, streamflow, and velocity and roughness conditions. Geometric survey was conducted by Dumpy level and measuring tape. Current meter and/or Flow-Tracker Handheld Acoustic Doppler Velocimeter (ADV) technology (ies) were used to measure velocity and stream flow. Fieldwork was conducted during low and medium flows. Reconnaissance survey preceded and guided the data collection activities.

\section{Hydraulic Analysis/Modelling Approach}

To interpolate or extrapolate hydraulic parameters other than the measured ones a hydraulic model in Physical Habitat Simulation Model (PHABSIM) was set up. However, the floodplain/swamps hydraulics studies in PRB were based on modelling in which a fully fledged river system hydraulic model was developed using HEC-RAS software.
The PHABSIM model has two components: hydraulic simulation and habitat simulations. The hydraulic simulation programs in PHABSIM assume that the shape of the channel does not substantially change with discharge over the range of flows being simulated. In practice, small changes in the bed topography will often occur between field data collection efforts at the high and low flows. If these differences are small, then they are ignored in the analyses. However, if significant changes in bed topography do occur between data collection field trips, these data should be treated as independent estimates of the hydraulic properties within the channel and used as independent data sets (evaluated as different project files) in the hydraulic model calibrations and subsequent habitat simulations.

The simulated hydraulic characteristics of the stream are the water surface elevations (i.e., depth) and velocities, in that order. Water depths are calculated in the habitat programs from water surface elevations simulated in the hydraulic programs. The water surface elevations are assumed to be the same across a single cross section (although depth varies since it is calculated by subtracting the bed elevation from the water surface level). In contrast, velocity varies from cell to cell across any cross section.

Table 3: Physical Descriptions of Some of the Study Sites

\begin{tabular}{|c|c|c|}
\hline Case study & Site No. & Physical description \\
\hline \multirow{3}{*}{ MRB (KY/TZ) } & ( & $\begin{array}{l}\text { Hydraulically complex reach and ill-defined river banks. Ideally } \\
\text { hydraulic river reaches require more data than simple sites. The } \\
\text { hydraulic control is a riffle (multi-hydraulic controls) }\end{array}$ \\
\hline & 2 & $\begin{array}{l}\text { Deep incised river channel. Well defined banks. Prismatic channel. } \\
\text { Straight reach. Uniform flow. Near ideal conditions for hydraulic } \\
\text { modelling. Defined state of flow. The hydraulic control is a riffle. }\end{array}$ \\
\hline & 3 & $\begin{array}{l}\text { Ill-defined river banks and terrestrial hydraulic controls such as } \\
\text { boulders downstream of the study reach. The hydraulic control is a } \\
\text { riffle. }\end{array}$ \\
\hline \multirow{3}{*}{ WRSB } & 1 & Raised banks. Sand river bed. Ephemeral stream. \\
\hline & 2 & $\begin{array}{l}\text { Straight channel reach. Shallow banks. Uniform flow. A fair hydraulic } \\
\text { control is located near the bridge downstream }\end{array}$ \\
\hline & 3 & Uniform flow. Sand/silt bed. Raised banks. Straight channel. \\
\hline
\end{tabular}




\begin{tabular}{|c|c|c|}
\hline Case study & Site No. & Physical description \\
\hline & & $\begin{array}{l}\text { Trapezoidal channel. Vegetated banks. Exposed roots in the banks. } \\
\text { Isolated dunes on the bank toes. Fallen trees. Prismatic channel. } \\
\text { Moderate bank slopes. }\end{array}$ \\
\hline & 4 & $\begin{array}{l}\text { Pronounced hydraulic control at low and moderate flows. Only portion } \\
\text { of the river reach is braided. Directional flow. Bed rock river bed. } \\
\text { Moderate bank slopes. Low lying banks }\end{array}$ \\
\hline & 5 & $\begin{array}{l}\text { Incised channel. Raised banks. Sand bed. Straight channel. Fair } \\
\text { hydraulic control- sand dunes. Standing waves. }\end{array}$ \\
\hline \multirow[t]{2}{*}{ GRRB } & 1 & $\begin{array}{l}\text { Ill-defined and low-lying left channel bank. Sand bars, terrestrial } \\
\text { hydraulic controls such as boulders downstream of the study reach. The } \\
\text { hydraulic control is a riffle. }\end{array}$ \\
\hline & 2 & $\begin{array}{l}\text { Incised channel. Raised eroding banks. Sand bed. Braided channel } \\
\text { pattern at low stages. Fair hydraulic control- sand dunes. }\end{array}$ \\
\hline
\end{tabular}

The approaches available for calculation of water surface elevations are: (1) stagedischarge relationships, STGQ; (2) Manning's equation, MANSQ, (Equation 1); and (3) the step backwater method using conservation of energy equation, WSP, (Equation 2). The absolute minimum data set used in the application of PHABSIM requires at least one set of water surface elevations. In standard practice, at least three sets of water surface elevations are targeted for collection along with at least one and preferably additional sets of velocity measurements.

$Q=\left[\frac{1}{n} * S^{1 / 2}\right] * A^{*} R^{2 / 3}$

$H=z+d+\frac{v^{2}}{2 g}$

In PHABSIM, the VELSIM program is the principal tool used to simulate the velocity distributions within a cross section over the required range of discharges (i.e., the mean column velocity in each wetted cell in a study cross section at each simulation discharge). The technique relies on an empirical set of velocity observations (i.e., measured velocities) that act as a template to distribute velocities across a channel by solving for the ' $n$ ' in Manning's equation (in this context ' $n$ ' acts as a roughness distribution factor across the channel). The channel is divided into cells and the velocity calculated for each of these cells (Equation 3). The usual practice is to use one set of velocities as a template for simulating velocities for a particular range of discharges. When more than one set of empirical velocity measurements is available, a commensurate number of flow ranges can be simulated with different velocity templates. The program can be used when no velocity measurements are available. In this situation, velocity will be distributed across the cross section as a function of flow depth.

$$
v(k)=\frac{\left.\mid a(k) r(k)^{0.667}\right\rfloor / n(k)}{\sum_{j=1}^{n c}\left[a(j) r(j)^{0.667}\right] / n(j)} Q_{s}
$$

Where: $a(j)$ denotes the area of the cell $j$; $r(j)$ denotes the hydraulic radius of the cell $\mathrm{j} ; \mathrm{n}(\mathrm{j})$ denotes the roughness of the cell $\mathrm{j}$; $\mathrm{nc}$ denotes the total number of wet cells in a cross section; and QS denotes the streamflow from which the velocity is being calculated.

The current HEC-RAS Software contains four one-dimensional river analysis components for: (1) steady flow water surface profile computations; (2) unsteady flow simulation; (3) movable boundary sediment transport computation; and (4) water quality analysis. The one-dimensional 
steady flow hydraulic model is designed to aid hydraulic engineers in channel flow analysis and floodplain determination. The steady flow describes conditions in which depth and velocity at a given channel location do not change with time. The unsteady version introduces many more parameters and increases data requirements, especially for the calibration, hence not adopted for this study. The primary procedure used by HEC-RAS to compute water surface profiles assumes a steady, gradually varied flow scenario, and is called the direct step method. The basic computational procedure is based on an iterative solution of the energy equation (Equation 4).

$$
H=z+d+\frac{\alpha v^{2}}{2 g}
$$

Which states that the total energy, $\mathrm{H}$, at any given location along the stream is the sum of potential energy, $\mathrm{Z}+\mathrm{d}$, and Kinetic energy $\frac{\alpha v^{2}}{2 g}$. The change in energy between two cross sections is called head loss, HL. As a consequence, only basic parameter appears: the friction coefficients, in addition to geometric data. HEC-RAS computes water levels and other average hydraulics. HEC-RAS is able to simulate at once up to 2000 different flow regimes, and boundary conditions are easily modified.

The models selected for this study demand less in terms of data and model application training and include only a few parameters. This enables us to collect the necessary data from the field. Moreover, EFA hydraulics doesn't require complex models, since distribution of biota is mainly a function of frequency and amplitude of floods. The models can simulate water levels and flow data for several discharges (habitatparameter curves), or changing boundary conditions.

Application of hydraulic programs available in PHABSIM interface relied on the availability of data. Observed data from geometric surveys and stream-discharge measurements were used to set up MANSQ, WSP, and VELSIM subprograms contained in PHABSIM model for the study sites. Input data for the model included cross section geometry, one velocity set, and observed mean discharge. These data were from low flow season fieldwork, which represents critical conditions for stream biota. It is therefore reasonable in EFA process to illustrate the stream flow parameters, which are representative of these conditions. The optimized sensitive parameters include roughness number, Beta, and Roughness modifier. An initial value for channel roughness (n) for use in the model was determined from reported literature values (Bovee and Cochnaur, 1987; Chow, 1959). Stage of Zero Flow was measured from the field. The model was calibrated in two steps. First, attempt was made to match simulated and observed water-surface elevations with reasonable accuracy. Generally, errors, which are in order of 3.0 to $6.0 \mathrm{~mm}$ were accepted. Secondly, attempt was made to match simulated and observed velocities at each transect for the calibration discharges. Testing of the model was based on medium flow field data and/or bankfull discharge information from neighbouring stations. Besides, previous study findings, professional experience/ judgments and field observations of flow regimes complemented the model validation exercise. For instance, as reported in Waddle (2001) the longitudinal profile of the simulated water surface elevations should always be checked to ensure water is flowing down hill between spatially linked cross sections in a study reach.

Building a model with HEC-RAS can be seen as a three-step sequence: drawing geometry of the system, calibration and testing. It requires two main types of data: geometric data and flow data. Geometric data are mainly used in the first step. They include river schematic, cross-sections, reach lengths, energy loss coefficients, stream junctions' information and hydraulic 
structures description. The geometric characteristics were derived from a calibrated NASA Shuttle Radar Topographic Mission (SRTM) Digital Elevation Models (DEM) of 90-m resolution under HEC-GeoRAS GIS extension Environment. The DEM was projected to Cartesian UTM coordinate system before being used to map the ground surface at the study area. The topographic sheets $(73 / 2,73 / 4,74 / 1$ and 74/3) at 1:50,000 scales, sourced from Surveys and Mapping Division of the Ministry of Land, Tanzania were used to calibrate and validate the DEM. A regression equation was established between DEM and elevations from topographic maps and the equation was used to calibrate the DEM.

The data was processed using Geographical Information System (GIS) software Arcview $3.2 \circledR$ with tools for filling pits, streamflow generation and delineation of catchments. It should be noted that the model requires a high-density of crosssections to run without displaying warnings. Flow data are then entered into the model. The data include discharges, flow regime observations (super- or sub-critical), and boundary conditions (i.e., known water surfaces, critical depth, energy slope or rating curve). Model parameters such as channel roughness (n) for use in the model was determined from reported literature values (Chow, 1959). Testing of the model was based on field observation, previous report and personal interviews of residents, fishermen, utility workers, and others who have many years of familiarity with the river system. The performance of the models during calibration and/or validation was quantified using relative error criterion in percent.

\section{RESULTS AND DISCUSSIONS}

As depicted from Figure 2 and Table 4 calibrated hydraulic models performed satisfactorily with most of the model performances based on relative error indices fell below 20\%. Besides, a few cases such as those of Site 1 of Mara River and Site 4 of Wami River were underperforming with higher relative errors. An independent analysis indicates that this is due to transcription errors (Ndomba, 2007). Such inconsistencies in the model performance were attributed to data manipulation and/or handling error.

Table 4: $\quad$ Sample Results for Selected Projects and Sites

\begin{tabular}{|l|c|c|c|c|}
\hline \multirow{3}{*}{ Case study } & \multirow{2}{*}{ SiteNo. } & \multirow{2}{*}{$\begin{array}{l}\text { Water profiles } \\
\text { (calibration) }\end{array}$} & $\begin{array}{l}\text { Relative errors (\%) for model } \\
\text { calibration/validation }\end{array}$ \\
\cline { 3 - 5 } & & Velocity (calibration) & Velocity (validation) \\
\hline \multirow{3}{*}{ MRB (KY/TZ) } & 1 & $0-0.08$ & $15 .-168.8$ & $9.7,28.0$ \\
\cline { 2 - 5 } & 2 & $0-0.06$ & $0.4-13.7$ & $3.6-11.3$ \\
\cline { 2 - 5 } & 3 & $0-0.24$ & $5.3-12.9$ & $7.3-17.5$ \\
\hline \hline \multirow{4}{*}{ WRSB } & 1 & $0-0.02$ & - & - \\
\cline { 2 - 5 } & 2 & $0-0.01$ & $6.5-119.6$ & \\
\cline { 2 - 5 } & 3 & $0-0.01$ & $5.2-38.0$ & 49.4 \\
\hline \multirow{2}{*}{ GRRB (TZ) } & 4 & 0.0 & $7.7-11.9$ & - \\
\cline { 2 - 5 } & 5 & $0-0.02$ & $1.1-20.1$ & - \\
\hline
\end{tabular}




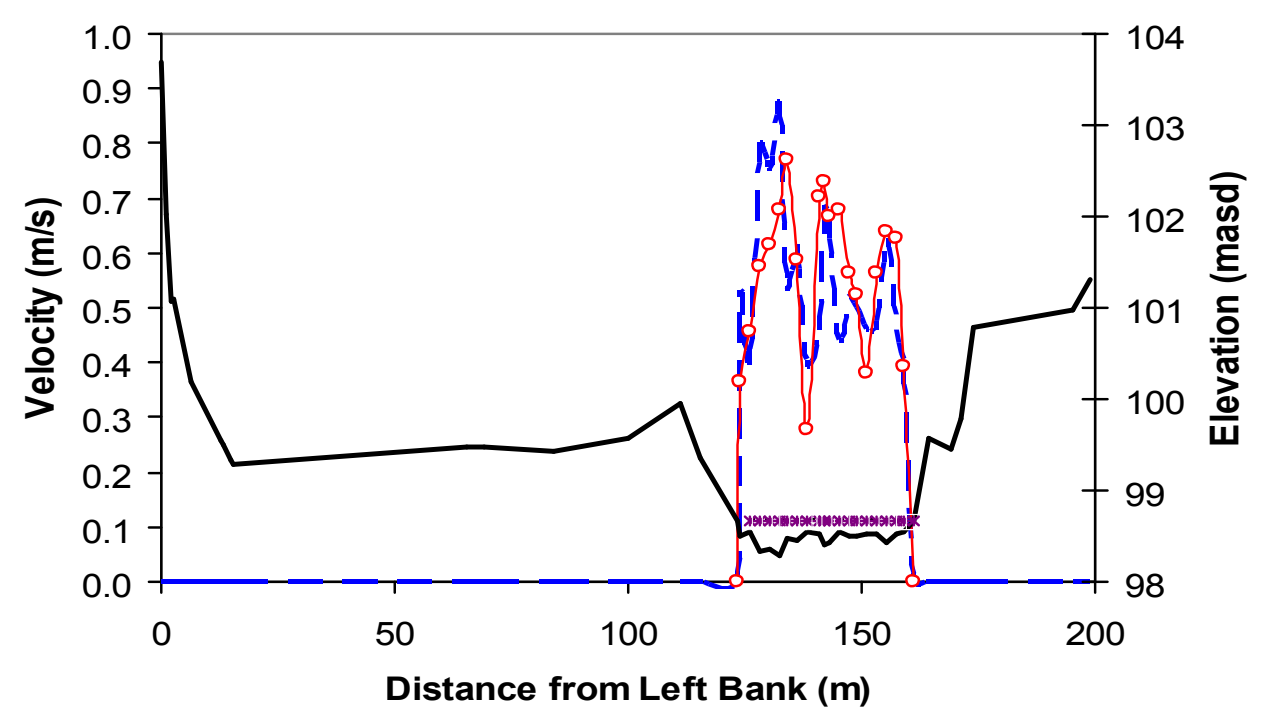

Distance from Left Bank (m)



Figure 2: $\quad$ Calibration results of one of the cross sections at Site 2 of WRSB study case.

Derived floodplain geometry from DEM in PRB is shown in Figure 3. The floodplain/swamps hydraulic modelling results indicated that a flood of $112 \mathrm{~m}^{3} / \mathrm{s}$ is enough to inundate about $70 \%$ of the swamps as shown in Figure 4. This result was independently confirmed from the interviews in the local area and from the historical data. In Figure 5, the relationships for five (5) sites in Wami River System are overlaid in one plot for the comparison purposes. The plot indicates the variation of wetted perimeter with streamflow discharge. The relationships in the plot fell within the dry and bankfull discharge ranges for each site. There was an abrupt increase in wetted perimeter for flow above $50 \mathrm{~m}^{3} / \mathrm{s}$ at Site 2. The site represents the upland sub-catchment condition, while the rest are located in the main Wami River reach. 




Figure 3: $\quad$ Typical Cross-Section for Kirua Swamp Derived from DEM

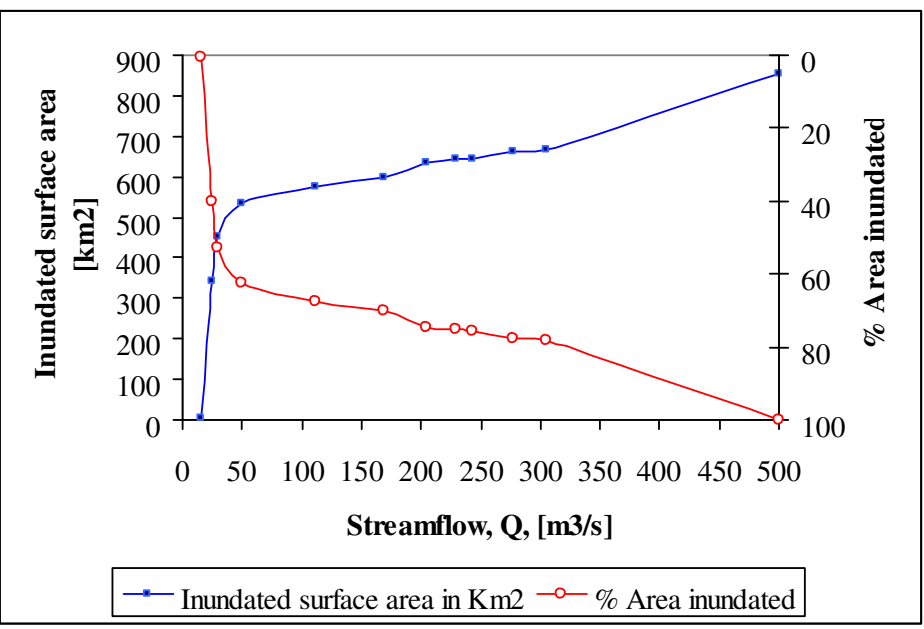

Figure 4: $\quad$ Relationship between Streamflow and Inundated Area for Kirua Swamp 


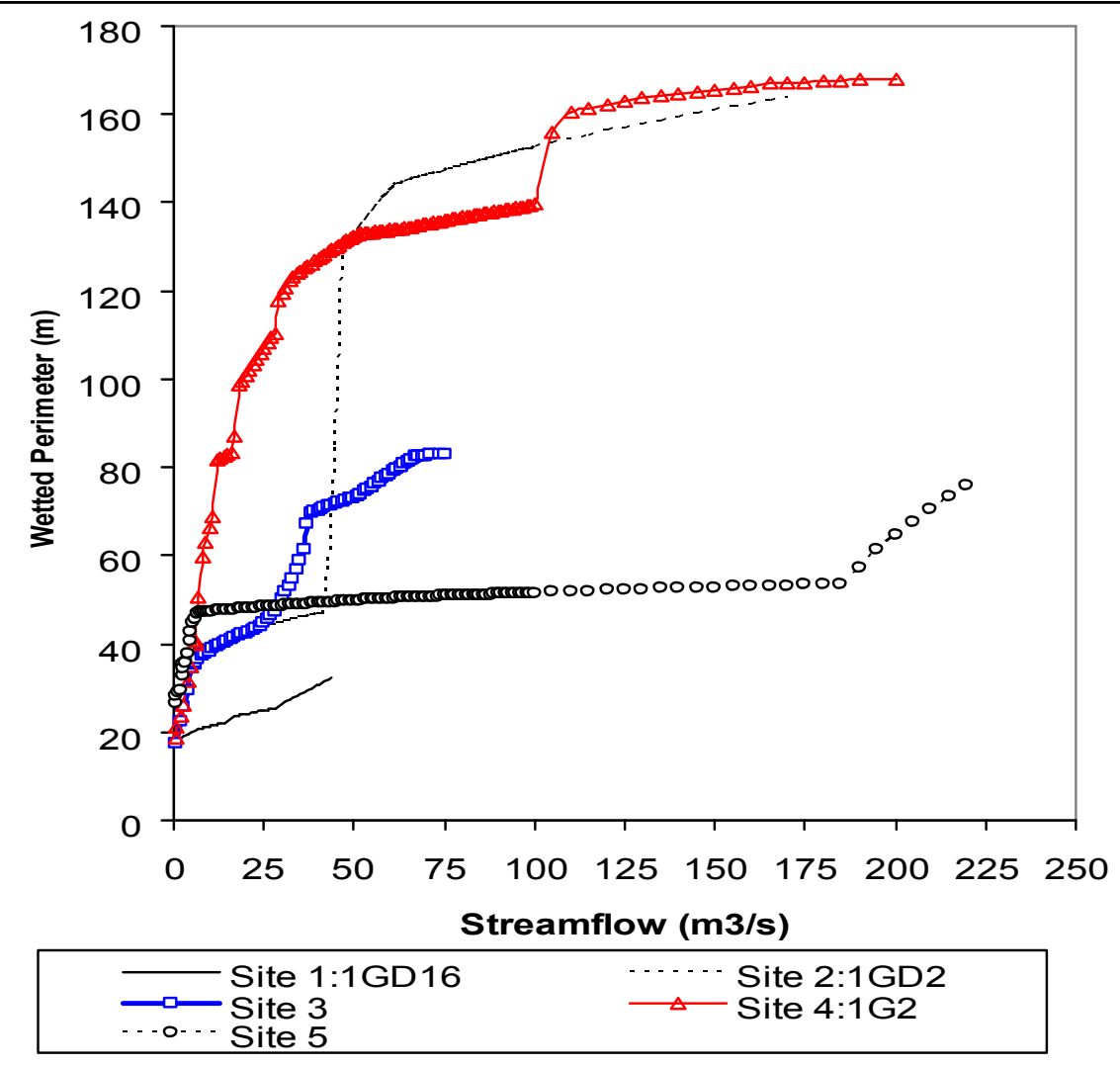

Figure 5: $\quad$ Relationship between Stream Flow and the Wetted Perimeter for the Sites in Wami River Basin

Table 5: $\quad$ Confidence Rating for Selected Projects and Sites

\begin{tabular}{|c|c|c|c|c|}
\hline \multirow{2}{*}{$\begin{array}{l}\text { Case } \\
\text { study }\end{array}$} & \multirow[b]{2}{*}{ Site No. } & \multicolumn{3}{|c|}{ Ratings $(1-5)$} \\
\hline & & Info/Data Availability & $\begin{array}{c}\text { Understanding of } \\
\text { hydraulics }\end{array}$ & $\begin{array}{l}\text { Recommended } \\
\text { flows }\end{array}$ \\
\hline \multirow{3}{*}{$\begin{array}{l}\text { MRB } \\
(\mathrm{KY} / \mathrm{TZ})\end{array}$} & 1 & 2 & 2 & 3 \\
\hline & 2 & 3 & 3 & 4 \\
\hline & 3 & 3 & 3 & 3 \\
\hline \multirow{5}{*}{$\begin{array}{l}\text { WRSB } \\
\text { (TZ) }\end{array}$} & 1 & 1 & 2 & 3 \\
\hline & 2 & 2 & 3 & 4 \\
\hline & 3 & 1 & 3 & 3 \\
\hline & 4 & 2 & 3 & 3 \\
\hline & 5 & 1 & 3 & 3 \\
\hline \multirow{2}{*}{$\begin{array}{l}\text { GRRB } \\
\text { (TZ) }\end{array}$} & 1 & 2 & 3 & 3 \\
\hline & 2 & 3 & 4 & 3 \\
\hline
\end{tabular}

The performance achieved in these studies is attributed to the instituted quality control measures right from suitable sites selection to hydraulic modelling phases. The measures in some sites included transcription errors identification during data analysis/processing. As indicated in Table 5 the confidence rating of the 
modelling results as compared to the recommended flows achieved is at least 3 in a scale of 5 for most of the study cases. Confidence rating was qualitatively determined and for a particular site depended upon the hydraulic complexity, data availability and range of flows recommended for Environment. However, some flood data and correct stage of zero flow, respectively, are required for validating and improving modelling performance.

\section{CONCLUSIONS AND RECOMMENDATIONS}

Most of the EFA studies in East Africa use Holistic Methodologies. An ideal data set for most of these methods would be six data points of stage measurements over a good distribution of discharges, plus a stage of zero discharge and some flood related data. In East African region studies suffer from data scarcity (i.e. poorly gauged sites) and limited expertise and funding.

The approach used in this study encompassed few data collection or site visits combined with desktop study and hydraulic modelling. The modelling results were considered satisfactory because the relative errors for most of applications fell below $20 \%$. The performance achieved in these studies is attributed to the instituted quality control measures right from suitable sites selection to hydraulic modelling phases. For instance, in some sites transcription errors were identified during data analysis, which suggests that researchers must be careful while using a few data points as some might be erroneous. Therefore quality control at all levels must be instituted. Confidence rating of the modelling results depended upon the hydraulic complexity. The confidence ratings of the modelling results are above 3 (out of 5), for most of the study cases.

Based on the good results in the study cases, it is evident that there are some prospects of carrying out hydraulic analysis satisfactorily in the region with limited data. However, professional input is the key to successful modelling. Follow up research should use more data to verify the approach adopted.

\section{ACKNOWLEDGMENT}

We would like to extend gratitude to the Clients of the authors offering the consultancy and allowing them to publish the technical part of the output. They include Wami-Ruvu Basin Water Office, Tanzania Water and Development Alliance, Florida International University, Pangani Basin Water Office, Rufiji Basin Water Office, The World Conservation Union (IUCN), World Wide Fund for Nature- East Africa Regional Programme Office (WWFEARPO) based in Nairobi, Kenya, and WWF-Tanzania Programme Office.

\section{REFERENCES}

Acreman, M. and Dunbar, J.M. (2004). Defining environmental river flow requirements - review. Centre for Ecology and Hydrology. UK. Hydrology and Earth System Sciences, 8(5): 861-876.

Acreman, M.C., King, J., Hirji, R., Sarunday, W. and Mutayoba, W. (2005). Capacity building to undertake environmental flow assessments in Tanzania. Proceedings of the International Conference on River Basin Management, Morogoro, Tanzania, March, 2005.

Allan, J.D. (1995). Stream Ecology structure and function of running waters. Chapman and Hall in Flow guidelines for instream values. Ministry of Environment, New Zealand.

Arthington, A.H. and Pusey B.J. (1993). In-stream flow management in Australia: methods, deficiencies and future directions. Australian Biologist, 6: 52-60. 
Biggs, B.J.F. (1982). Effects of low flow regulation on river water quality and biology: a case study. In R. H. S. McColl (eds). River low flows: conflicts of water use, pp. 28-44. Ministry of Works and Development, Wellington.

Bovee, K.D. (1982), A guide to stream habitat analysis using the IFIM. Report FWS/OBS-82/26, US Fish and Wildlife Service, Fort Collins, USA.

Bovee, K.D. (1997). Data collection procedures for the Physical Habitat Simulation System. Fort Collins, U.S. Geological Survey, Biological Resources Division, 141 p.

Bovee, K.D. and Cochnauer, T. (1987). Development and evaluation of weighted criteria, probability of use curves for instream flow assessments-fisheries. U.S. Fish and Wildlife Service, FWS/OBS77/63, 39.

Chow, V.T. (1959). Open-Channel Hydraulics. Tokyo, McGraw-Hill, $680 \mathrm{p}$.

Gippel, C.J. and Stewardson, M.J. (1998). Use of Wetted perimeter in defining minimum environmental flows. Regulated Rivers: Research and Management, 14: 53-67.

Jowett, I.G. (1992). River hydraulics and instream habitat modeling for river biota. In Mosely, M. P. (ed), Waters of New Zealand, 249-263.

King, J.M., Tharme, R.E. and Villiers, M.S. (2000). Environmental Flow Assessment for Rivers: Manual for the Building Block Methodology. Water Research Commission (WRC) Report No. TT 131/00. ISBN 186845628 5. South Africa.

Mati B.M., Simon M., Patrick, H., Mtalo, F. and Gadain, H. (2005). Land Use Changes in the Transboundary Mara Basin: A Threat to Pristine
Wildlife Sanctuaries in East Africa. Unpublished Report. Department of Water Resources Engineering, University of Dar es Salaam.

McClain, M., Kashaigili, J. and Ndomba, P.M. (2013). Environmental Flow Assessment as a Tool for Achieving Environmental Objectives of African Water Policy. International Journal of Water Resources Development, 29(4): 650-665.

Ndomba, P.M. (2007). Environmental Flows Assessment of Mara River in Masai Mara Game Reserve, Kenya and Serengeti National Park, Tanzania. Starter document for Hydraulic Component submitted to WWF Eastern Africa Regional Programme Office (EARPO) based in Nairobi Kenya. September 5, 2007.

Ndomba, P.M. (2013). Use of accurate data and information for sustainable management and development of water resources: challenges and approach. A case study of Wami River Sub-basin in Tanzania. A book chapter submitted to Springer.

Tharme, R.E. (1996). Review of international methodologies for the quantification of the instream flow requirements of rivers. Water Law Review: final report for policy development, South African Department of Water Affairs and Forestry. Freshwater Research Unit, University of Cape Town, Pretoria. $116 \mathrm{p}$.

Waddle, T.J. (2001). PHABSIM for Windows-user's manual and exercises: U.S. Geological Survey Open-File Report, 01-340, 288 p.

Mwamila, T.B., Kimwaga, R.J. and Mtalo, F.W. (2008). Eco-hydrology of the Pangani River downstream of Nyumba ya Mungu reservoir, Tanzania. Journal of Physics and 
Problems and Prospects of Hydraulic Modelling for Environmental Flows Assessment Studies in East Africa

Chemistry of the Earth, 33: 695-699. ISSN 1474-7065. 